\title{
An Assessment of Some Toxic, Essential Elements and Natural Radioactivity, in Most Common Fish Consumed in Jeddah-Saudi Arabia
}

\author{
Safia H. Q. Hamidalddin*, Jameelah H. AlZahrani \\ Physics Department, Faculty of Science, Al Faisaliah campus, King Abdulaziz University, Jeddah, \\ Saudi Arabia \\ Email: "Shamidaddin@kau.edu.sa, 'Safiahqh@yahoo.com
}

Received 28 February 2016; accepted 25 April 2016; published 28 April 2016

Copyright (C) 2016 by authors and Scientific Research Publishing Inc.

This work is licensed under the Creative Commons Attribution International License (CC BY). http://creativecommons.org/licenses/by/4.0/

(c) (i) Open Access

\section{Abstract}

This study has been carried out to determine the concentrations $\mathrm{mg} / \mathrm{Kg}$ of the toxic elements ( $\mathrm{Al}$, $\mathrm{Hg}, \mathrm{Cd}, \mathrm{Pb}, \mathrm{U}$, Th, and $\mathrm{As}$ ) and essential elements (K, $\mathrm{Sn}, \mathrm{Ca}, \mathrm{Ni}, \mathrm{Cu}, \mathrm{Fe}, \mathrm{Co}$, and $\mathrm{Mn}$ ) using inductively coupled plasma optical emission spectrometer, and the radionuclides concentration levels of ${ }^{238} \mathrm{U}$, ${ }^{226} \mathrm{Ra},{ }^{232} \mathrm{Th},{ }^{40} \mathrm{~K}$ and ${ }^{137} \mathrm{Cs}$ ) using a high purity germanium spectrophotometer in ten of the most common fish samples collected from local store in Jeddah city, Saudi Arabia during 2014. The results showed that, the concentrations of the elements ( $\mathrm{Al}, \mathrm{Hg}, \mathrm{Pb}$ and $\mathrm{Cu}$ ) in all fish samples were not detected or below the detection limit. The concentrations of metals (Cd, U, Th, As, K, Sn, Ca, Ni, $\mathrm{Fe}, \mathrm{Co}$, and $\mathrm{Mn}$ ) were below the recommended limit by the international organizations. The estimated metal dose (EDI) values for daily average consumption were lower than the recommended values by FAO/WHO, and hazard indices (HI) in fish samples were below safety levels for human consumption $(\mathrm{HI}<1)$ except $(\mathrm{HI})$ for Ca element with values were greater than one $(>1)$, then this increase is to be of concern for fish consumer. The measured concentrations in (Bq/ $\mathrm{Kg})$ dry weight of natural radionuclides ${ }^{238} \mathrm{U},{ }^{226} \mathrm{Ra},{ }^{232} \mathrm{Th},{ }^{40} \mathrm{~K}$ and fallout ${ }^{137} \mathrm{Cs}$ in fish samples were calculated. The results show that the activities in fish samples were of no risk to public health. The total average annual effective dose $\mu \mathrm{Sv} / \mathrm{y}$ due to intake of ${ }^{238} \mathrm{U},{ }^{226} \mathrm{Ra},{ }^{232} \mathrm{Th}$ and ${ }^{40} \mathrm{~K}$ from the ingestion of the fish samples were estimated to be 6.07 for infants $(\leq 5 Y), 22.88$ and 45.03 for children $(5-10 Y$ and 10 - $15 \mathrm{Y}$ ) and 56.26 for adults ( $\geq 17 \mathrm{y})$, which are lower than the allowed value (1 mSv). The contribution of ${ }^{137} \mathrm{Cs}$ is nearly negligible. This study could be useful as a baseline data for toxic, essential metals, and radiation, exposure.

\footnotetext{
${ }^{*}$ Corresponding author.
}

How to cite this paper: Hamidalddin, S.H.Q. and AlZahrani, J.H. (2016) An Assessment of Some Toxic, Essential Elements and Natural Radioactivity, in Most Common Fish Consumed in Jeddah-Saudi Arabia. Food and Nutrition Sciences, 7, $301-311$. http://dx.doi.org/10.4236/fns.2016.74032 
Keywords

Natural Radioactivity, Fish, Toxic and Essential Metals, Ingestion Dose

\section{Introduction}

Fish is consumed in many countries because it has high protein supplies, essential amino acids, vitamin, and mineral content. Fish are exposed to chemicals such as heavy metals in polluted and contaminated waters. Heavy metals from the human activities and resources are continually sent out into aquatic ecosystems, they are serious health risks due to of their toxicity, long persistence, bio concentration in the food chain [1]. Toxic elements such as mercury, arsenic, cadmium, and lead, can cause mental and central nervous system damage. It is important to check and control heavy metal levels in seafood, because heavy metal ions can easily accumulate in fish more than other foodstuffs. Lakes, rivers, stream, and sea are polluted by chemical substances, paints, petroleum products, and industrial, domestic, and modern agriculture wastes in the form of particles, metal ions, and organic and inorganic compounds. The heavy metal ions accumulation in seafood, including fish, becomes high. Heavy metals in organs of fish, such as internal organs, kidneys, and spleen, can be transmitted to and accumulated in organs of human body by their consumption. Fish is one of the most important foods to be eaten for a healthy life, therefore, heavy metals in food chain make threats to human health [2]. At low concentrations, heavy metals are toxic to fish, while essential elements ( $\mathrm{Zn}, \mathrm{Al}, \mathrm{B}, \mathrm{Ba}, \mathrm{Cr}, \mathrm{Fe}, \mathrm{Mn}, \mathrm{Ni}, \mathrm{Sr}, \mathrm{Cu}$ and $\mathrm{Co}$ ) become toxic at high concentrations [3]. Small fish become enriched with the accumulated substances in polluted aquatic systems. So, it can be used for pollution indicator and environmental changes study [4]. On the other hand, naturally occurring radionuclides Uranium $\left({ }^{238} \mathrm{U}\right)$, Radium $\left({ }^{226} \mathrm{Ra}\right)$, Thorium $\left({ }^{232} \mathrm{Th}\right)$, and potassium $\left({ }^{40} \mathrm{~K}\right)$ and the artificial radionuclides such as ${ }^{137} \mathrm{Cs}$ in the environment can be concentrated in and transferred along the food chains, damaging biological effects on populations and ecosystems may come from these ionizing radiation [5]. Great interests focus on the consumption of marine foodstuffs such as fish, seaweeds and manufactured products including radioactivity. The radiation dose received and accumulated in the body by marine fauna comes from the naturally occurring uranium series, ${ }^{210} \mathrm{Po}$ is alpha-emitting radionuclides and gives (90\%) of the natural radiation dose received by most marine organisms and the artificial ${ }^{137} \mathrm{Cs}$ has great abundant in the environment [6]. Radioactive contamination of the Pacific Ocean after the Fukushima nuclear accident has raised public worry about seafood safety. ${ }^{137} \mathrm{Cs}$ half-life is long and is found in the environment for a long time, so levels of cesium radiation and the consumption of contaminated fish are calculated, the results compare to International Commission on Radiological Protection annual dose limit (1 mSv to the public) [7]. In this study, ten samples were analyzed to calculate the concentrations (mg/Kg) of toxic elements (Al, Hg, Cd, Pb, U, Th, and As) and essential elements (K, Sn, $\mathrm{Ca}, \mathrm{Ni}, \mathrm{Cu}, \mathrm{Fe}, \mathrm{Co}$, and $\mathrm{Mn})$. Also, the concentrations in $(\mathrm{Bq} / \mathrm{Kg})$ dry weight of natural radionuclides ${ }^{238} \mathrm{U}$, ${ }^{226} \mathrm{Ra}$, ${ }^{232} \mathrm{Th}$ and ${ }^{40} \mathrm{~K}$ and the artificial radionuclide ${ }^{137} \mathrm{Cs}$ in the fish samples were measured. The total average annual effective dose due to intake of natural radionuclides from the ingestion of the fish samples were estimated for infants, children, and adults also, the estimated metal dose (EDI) values for daily average consumption and hazarded index (HI) in fish samples were calculated to determine and monitor the serious health risks due to the consumption of contaminated fish.

\section{Materials and Methods}

\subsection{Collection and Preparation Samples}

Ten samples were taken from the local markets in Jeddah-Saudi Arabia. The samples data of fish (i.e. Scientific Name, Common Name, Country of Origin, Type, Collection Time) are indicated in Table 1. The fish species were collected from random commercial market depending on the availability of the species for sale at April 2014. Samples obtained were cleaned, thawed on, cut to pieces and dried to constant weight at $110^{\circ} \mathrm{C}$. These samples were ground into powder and stored in polyethylene bags.

\subsection{Instrumentation}

Half (0.5) gm of the fish samples were analyzed by Inductively coupled plasma optical emission spectrometry 
Table 1. Information of fish collected from the local markets in Jeddah- Saudi Arabia.

\begin{tabular}{|c|c|c|c|c|c|}
\hline $\begin{array}{l}\text { Sa. } \\
\text { No. }\end{array}$ & Scientific Name & $\begin{array}{c}\text { Common } \\
\text { Name }\end{array}$ & Country of Origin & Type & Collection Time \\
\hline S1 & Siganus rivulatus & Seagan & South Yemen Gulf of Aden & Fresh & $16 / 4 / 2014$ \\
\hline S2 & Rastrelliger kanagurta & Bagha & Saudi Arabia & Fresh & $27 / 4 / 2014$ \\
\hline S3 & Oreochromis niloticus & Tilapia & Egypt Nile River & Fresh & $27 / 4 / 2014$ \\
\hline S4 & Sardinops sagax & Sardine & Saudi Arabia & Fresh & $27 / 4 / 2014$ \\
\hline S5 & Clupea & Herring & Philippines & Frozen, Po.:25/10/2012 Ex.:24/10/2015 & $27 / 4 / 2014$ \\
\hline S6 & Pangasius hypophthalmus & Catfish & Vietnam & Frozen, Po: 03/07/2013 Ex.:03/07/2015 & $27 / 4 / 2014$ \\
\hline S7 & Caridea & Shrimp & United Arabia of Emirates & Frozen, Po: 02/02/2014 Ex.:02 /02/2016 & $27 / 4 / 2014$ \\
\hline S8 & Oreochromis niloticus & Tilapia & Taiwan & Frozen, Po.:10 /09/2013 Ex.:10 /09/2015 & $27 / 4 / 2014$ \\
\hline S9 & Alalunga & Tuna & Thailand & Canned, Po14 /11/2013 Ex.:14/11/2015 & $27 / 4 / 2014$ \\
\hline S10 & thynnus & Tuna & Indonesia & Canned, Po 09/12/2013 Ex.:09/12/2015 & $27 / 4 / 2014$ \\
\hline
\end{tabular}

(ICP-OES) (Perkin Elmer- Optima 8300 ICP-OES Spectrometer) to get the concentrations of toxic elements (Al, $\mathrm{Hg}, \mathrm{Cd}, \mathrm{Pb}, \mathrm{U}$, Th, and $\mathrm{As}$ ) and essential elements (K, Sn, $\mathrm{Ca}, \mathrm{Ni}, \mathrm{Cu}, \mathrm{Fe}, \mathrm{Co}$, and $\mathrm{Mn}$ ) in fish samples. For radiometric analyses, each dried sample was weighed, put, and sealed in 640 cc polyethylene Marinelli beakers then stored for nearly 4 month under $27^{\circ} \mathrm{C}$ to prevent the escape of Radon gas and to allow the attainment of radioactive secular equilibrium between ${ }^{238} \mathrm{U}$ series and ${ }^{232} \mathrm{Th}$ series. The radioactive nuclei concentrations in the samples were determined using High purity Germanium (HPGe) coaxial detector with relative efficiency of 25\% and FWHM $2.0 \mathrm{keV}$ at $1332 \mathrm{keV}$, of ${ }^{60} \mathrm{Co}$. To reduce gamma ray background (HPGe) Detector was surrounded by lead shielding Genie 2000 basic spectroscopic software was installed in the computer for data acquisition and analysis. The system was calibrated for energy and absolute efficiency. The lowest limits of detection (LDL) were calculated tobe0.311, 0.312, 0.34, 1.66, and $0.45 \mathrm{~Bq} / \mathrm{Kg}$ for ${ }^{238} \mathrm{U},{ }^{226} \mathrm{Ra},{ }^{232} \mathrm{Th},{ }^{137} \mathrm{Cs}$, and ${ }^{40} \mathrm{~K}$ respectively. To collect the background count rates, an empty polyethylene Marinelli beaker was placed in the detection system. The measurements were done for a counting time of 82,800 sec.

\subsection{Calculations}

1) Assessments of heavy metals hazard index (HI) in fish samples:

A hazard index (HI) may be used to describe the risk from metals intake through ingestion. The hazard index (HI) was calculated by using the equation below [8] [9]:

$$
H I=E D I / R_{f} D
$$

It is the ratio of the estimated metal dose $\left(E D I \mathrm{mg} / \mathrm{Kg}\right.$ of body weight per day) and the reference dose $\left(R_{f} D\right.$ $\mathrm{mg} / \mathrm{kg} /$ day). If $H I>1.0$, then the $E D I$ of a particular metal exceeds the $R_{f} D$, pointing out that there is a potential risk associated with that metal.

The estimated daily intake (EDI) was determined using the following equation [10] [11]:

$$
E D I=C_{\text {metal }} \times W / m
$$

where: $C_{\text {metal }}$ is the metal concentration level of metals in fish; $\mathrm{W}$ represents the daily average consumption of fish is given as: $0.003,0.025$, and $0.068 \mathrm{~kg} /$ day for Infants, children and adults respectively [12], $\mathrm{m}$ is the body weight of $10 \mathrm{~kg}$ for Infants, $30 \mathrm{~kg}$ for children and $70 \mathrm{~kg}$ for adults.

2) Activity concentrations:

The photon energies of63.29 and $92.57 \mathrm{keV}$ were used to calculate ${ }^{238} \mathrm{U}$ average concentration and the photon energies of $351.87 \mathrm{keV}$ of ${ }^{214} \mathrm{~Pb}$ and 609.31 and $1120.27 \mathrm{keV}$ of ${ }^{214} \mathrm{Bi}$ were used to find the average concentration of ${ }^{226} \mathrm{Ra}$ (since there is a secular radioactivity equilibrium between ${ }^{226} \mathrm{Ra}$ progenies). The average concentration of ${ }^{232} \mathrm{Th}$, which it is in a secular radioactivity equilibrium with its short half-life daughters, was determined using the gamma lines of ${ }^{228} \mathrm{Ac}(338.32,911.16$, and $968.97 \mathrm{keV})$ and of ${ }^{208} \mathrm{Tl}(583.10 \mathrm{keV})$. The analysis of ${ }^{40} \mathrm{~K}$ and ${ }^{137} \mathrm{Cs}$ concentrations was based on their peaks in the spectrum at energies 1460.80 and $661.66 \mathrm{keV}$ respectively. 
Determination of activity concentrations in Bq/kg dry weight was calculated using the flowing equation [13]:

$$
A=\frac{C}{m \beta \varepsilon}
$$

where: $C$ is the count per second of the net peak area of specific gamma ray energy. $m$ is the mass of the samples in $(\mathrm{kg}) . \beta$ is the transition probability of gamma-decay. $\varepsilon$ is the detector absolute efficiency at the specific gamma-ray energy.

3) Annual effective dose:

Annual radionuclide intakes and effective doses for fish consumers age groups as (infant ( $\leq 5 \mathrm{Y})$, children (5 $10 \mathrm{Y}$ and $10-15 \mathrm{Y}$ ), and adults ( $\geq 17 \mathrm{Y})$ ) were calculated using the equation [14]:

$$
D=C A R
$$

where: $D$ is the effective dose by ingestion of the radionuclide ( $\mathrm{Sv} / \mathrm{Y}), \mathbf{A}$ is the activity concentration of the radionuclides in the sample $(\mathrm{Bq} / \mathrm{kg}), C$ is the internal dose conversion factor by ingestion of the radionuclides $(\mathrm{Sv} / \mathrm{Bq})$ which varies with both radioisotopes and the age of the individual were reported by (ICRP) [7], $R$ is the annual intake of fish $(\mathrm{Kg} / \mathrm{Y})$ which is calculated for different age groups of population. In our study the average mass of the fish consumed by the infants (age $\leq 5 \mathrm{y}$ ), children (age 5 - 10 y and $10-15 \mathrm{y}$ ) and adults (age from $17 \mathrm{y}$ and above) were $1 \mathrm{~kg} / \mathrm{y}, 5 \mathrm{~kg} / \mathrm{y}, 10 \mathrm{~kg} / \mathrm{y}$ and $25 \mathrm{~kg} / \mathrm{y}$, respectively .

\section{Results and Discussion}

\subsection{Elements Concentrations Using Inductively Coupled Plasma Optical Emission ICP- OES) Spectrometry}

Table 2 shows the corresponding concentrations of toxic and essential elements in $\mathrm{mg} / \mathrm{Kg}$ of analyzed fish samples namely (Seagan, Bagha, Tilapia, Sardine, Herring, Catfish, Shrimp, Tuna) using inductively coupled plasma optical emission (ICP-OES) spectrometry.

Toxic elements:

Aluminum (Al) is a trace element in fish. The results obtained shows that Al concentrations were not detected (ND) in the fish samples from 1 to 8, samples 9 and 10 (Tuna) were lower than detection limits (LDL ${ }^{*}$ ).

Mercury (Hg) is a heavy element in fish, the existing of this element in food such as fish may cause risk on human health. Table 2 represents the Hg for all fish species were (ND).

Cadmium (Cd) highest concentrations mg/Kg were in fresh Seagan, frozen Tilapia, and fresh Sardine (0.015, 0.019, 0.022) respectively. On the other hand, the lowest Cd concentrations $\mathrm{mg} / \mathrm{kg}$ were in frozen Herring, Shrimp, and canned Tuna (0.001, 0.002, 0.002, 0.03). For the rest of samples analyzed, cadmium concentrations were low or not detected.

Lead (Pb) is heavy element and can be found in fish directly from seawater and sediments and exists in the fish consumers' tissues. It is harmful to human health at high concentrations, the allowed limit is $0.2 \mathrm{mg} / \mathrm{kg}$ [15]. In this study, Pb was not detection (ND), so there is no risk to fish consumers.

Uranium (U) is a radioactive metal, but Uranium's toxic hazard resides not only in its radiation effects but in its chemical effects [16]. Results show that highest U concentrations mg/kg were in fresh Bagha and Tilapia (3.086, 4.906, 5.075). For all samples, the concentrations $\mathrm{mg} / \mathrm{Kg}$ ranged from 0.519 to 5.075 .

Thorium (Th) is a naturally-occurring, radioactive metal. Since Thorium is found almost everywhere, all people absorb some through food, drinking water, and in air. Th concentrations of fish species ranged from ND to $0.032 \mathrm{mg} / \mathrm{kg}$. The concentration in frozen Tilapia was LDL.

Arsenic (As) presents in fish consumed by human. It is a toxic and trace element and inorganic arsenic is found at very low concentrations in fish and other seafood products, some types of fish have high concentrations. In this work, values for As ranged from ND for canned Tuna to $0.752 \mathrm{mg} / \mathrm{kg}$ for fresh Sardine. All the samples analyzed were below the maximum allowed limit put by Brazilian legislation (1 mg/kg).

Essential element

Potassium (K): All fish contain potassium. It is necessary for human health, but deficiency or increase in potassium intake is a risk for human, the recommended daily dietary intake of potassium (in Australia) for adults is 2.0 - $5.5 \mathrm{~g}$ ). The lowest k concentration determined in fish species was found as $21.017 \mathrm{mg} / \mathrm{kg}$ in frozen shrimp and the highest $176.571 \mathrm{mg} / \mathrm{kg}$ in frozen Herring. 


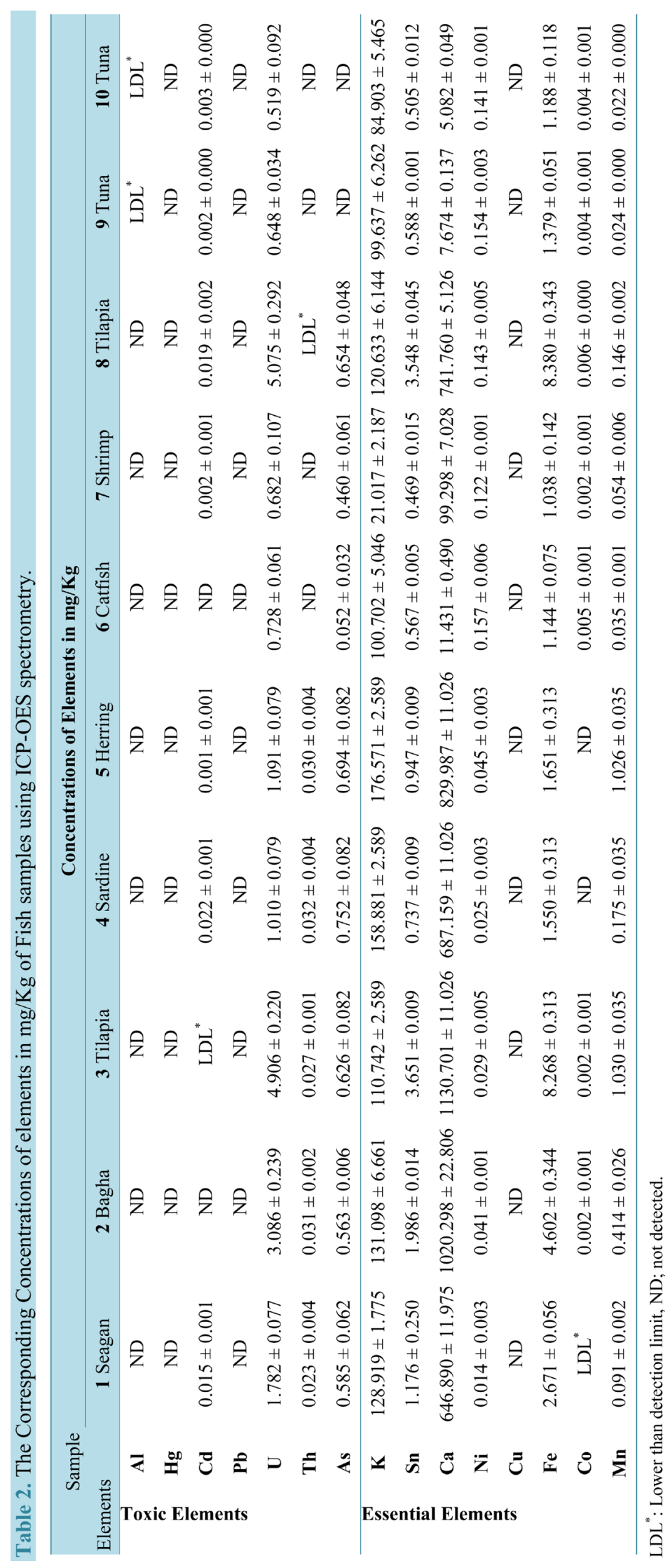


Tin (Sn) is an essential element in fish and becomes toxic when the tin migrate from the container to canned fish. In this work, the highest concentration of tin 3.651 and $3.548 \mathrm{mg} / \mathrm{kg}$ in fresh and frozen Tilapia, the lowest values $0.469 \mathrm{mg} / \mathrm{kg}$ in frozen Shrimp. The concentration values in $\mathrm{mg} / \mathrm{kg}$ were 0.505 and 0.588 in canned Tuna.

Calcium (Ca) Calcium is an essential component of fish. The results indicated that, Ca concentrations values in mg/kg were high for fresh Tilapia 1130.70, fresh Bagha 1020.298, frozen Herring 829.987, frozen Tilapia 741.760, fresh Sardine 687.159, fresh Seagan 646.890, and frozen Shrimp 99.298, while the lowest values in $\mathrm{mg} / \mathrm{kg} 5.082,7.674$, and 11.431 for canned Tuna and Catfish respectively.

Nickel (Ni) is a trace element in fish. In this work, Ni has low values $\mathrm{mg} / \mathrm{kg}$ in fresh samples. The concentrations of $\mathrm{Ni}$ in all the samples were far below the allowed limit 70 - $80 \mathrm{mg} / \mathrm{kg}$ [17].

Copper (Cu) makes health hazard when it took in large amount exceeded the allowable limit by the World Health Organization and Food and Agriculture Organization, $30 \mathrm{mg} / \mathrm{kg}$. Table 2 shows that the concentrations of copper in fish samples were not found.

Iron (Fe) is essential element to all living and the allowable limit by the National Health and Medical Research Council National for Food Standard is $8.76 \mu \mathrm{g} / \mathrm{g}$. In this work, the highest concentrations in $\mathrm{mg} / \mathrm{k}$ of iron were in Tilapia (8.380 sample 8 and 8.268 sample 3), these values are lower than the maximum allowed limits.

Cobalt (Co) is essential for red blood cell formation, the maintenance of nerve tissue, and useful for humans because it is part of vitamin B12. Rich dietary sources of cobalt include fish meal, but high levels of cobalt can cause lung and heart diseases. Cobalt concentrations in this work ranged from ND (fresh Sardine and frozen Herring) to 0.006 (frozen Tilapia) $\mathrm{mg} / \mathrm{kg}$. The results do not affect a risk to human.

Manganese (Mn) highest concentrations (1.030 and $1.026 \mathrm{mg} / \mathrm{kg}$ ) were detected in fresh Tilapia and frozen Herring, while the minimum values (0.022 and 0.024) were found in canned Tuna. Based on the above results, it can therefore be concluded that elements bioaccumulation in the fish samples under study did not exceeds the allowed limits set for metals by [18]. Therefore these fishes are healthy for consumption.

\subsection{Daily Intake of Metals and Hazard Index}

The daily intakes (EDI) of the metals were calculated using the average concentrations of metals in the fish samples and the average consumption of fish per day for age groups infants, children, and adults as reported by [12]. The daily intakes (EDI) mg/kg body weight/day of toxic and essential elements were presented in Table 3. For $\mathrm{Al}$, (EDI) was lower than limit (LDL), and $\mathrm{Hg}, \mathrm{Pb}$, and $\mathrm{Cu}$, (EDI) were not found (ND). The daily intakes (EDI) $\mathrm{mg} / \mathrm{kg}$ body weight/day for infants, children, and adults of Cd were 2.74E-06, 7.62E-06, and 8.88E-06, for U, (EDI) were $0.59 \mathrm{E}-03,1.63 \mathrm{E}-03$, and 1.90E-03, (EDI) of Th were 2.48E-05, 6.88E-05, 8.03E-05. As (EDI) 1.37E-04, 3.82E-04, and 4.45E-04. The daily intakes (EDI mg/kg body weight/day for infants, children, and adults of essential elements were (K: 3.40E-02, 9.44E-02, 11.01E-02), (Sn: 1.08E-06, 3.00E-06, 3.50E-06, (Ca: 1.56E-01, 4.32E-01, 5.03E-01), (Ni: 2.61E-05, 7.25E-05, 8.45E-05), (Fe: 0.96E-03, 2.66E-03, 3.10E-03), (Co: 1.08E-06, 3.00E-06, 3.50E-06), and (Mn 9.05E-05, 2.52E-04, 2.93E-04). These results are lower than the recommended values by [12]. Estimated hazard index (HI) in fish samples do not affect a threat to the human health, where the HIs of the considered metals were less than one $(<1)$ [19], except (HI) for Ca element with values 7.80, 21.60, and $25.15 \mathrm{mg} / \mathrm{kg}$ body weight/day, (for infants, children, and adults) were greater than one $(>1)$, then this increase are to be of concern for fish consumer. The results were shown in Table 3.

Table 4 shows comparison between the concentrations $(\mathrm{mg} / \mathrm{Kg})$ of the toxic and the essential elements in the present study and the concentration values of the studies in other countries. The concentrations (mg/Kg) of the toxic and the essential elements in fish samples varied from one country to another due to the different types of fish and the environment in which these fish were lived as shown in these tables.

\subsection{Gamma Spectroscopy: Activity Concentration}

The measured concentrations in (Bq/Kg) dry weight of natural radionuclides ${ }^{238} \mathrm{U},{ }^{226} \mathrm{Ra}$, ${ }^{232} \mathrm{Th}$ and ${ }^{40} \mathrm{~K}$ in ten samples of fish collected from the local markets in Jeddah-Saudi Arabia are listed in Table $5 .{ }^{238} \mathrm{U}$ concentrations in $\mathrm{Bq} / \mathrm{kg}$ dry weight were from LDL to 2.69, for ${ }^{226} \mathrm{Ra}$ concentrations in $\mathrm{Bq} / \mathrm{kg}$ dry weight ranged from 0.75 to $2.70,{ }^{232} \mathrm{Th}$ concentrations in $\mathrm{Bq} / \mathrm{kg}$ dry weight were from 0.64 to 2.67 , whereas ${ }^{40} \mathrm{~K}$ and the artificial radionuclide ${ }^{137} \mathrm{Cs}$ concentrations in $\mathrm{Bq} / \mathrm{kg}$ dry weight existed in the range from 14.02 to 352.32 and from LDL to 1.44 respectively. The results showed that, the samples for fresh fish (1-4) and sample 5 for frozen fish have the highest radiation comparison with other samples, while the sample No. 10 (canned fish) has the lowest radiation. 
Table 3. Average Concentrations (mg/Kg), $\mathrm{R}_{\mathrm{f}} \mathrm{Ds} \mathrm{mg} / \mathrm{kg}$ body weight/day, EDIs (mg/kg body weight/day) and HI of elements in fish due to ingestion of infants, Children, and Adults.

\begin{tabular}{|c|c|c|c|c|c|c|c|c|c|}
\hline \multirow{2}{*}{\multicolumn{2}{|c|}{ Element }} & \multirow{2}{*}{$\begin{array}{l}\text { Average } \\
\text { Conc. } \\
\text { mg/Kg }\end{array}$} & \multirow{2}{*}{$\begin{array}{c}{ }^{*} R_{f} D \\
\text { mg/kg body } \\
\text { weight/day }\end{array}$} & \multicolumn{3}{|c|}{ EDI mg/kg body weight/day } & \multicolumn{3}{|c|}{ Hazard index (HI) } \\
\hline & & & & Infants & Children & Adults & Infants & Children & Adults \\
\hline \multirow{7}{*}{ 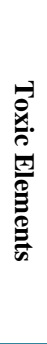 } & Al & LDL & $1.00 \mathrm{E}+01$ & ---- & ----- & ----- & ----- & ----- & ----- \\
\hline & Hg & ND & $5.70 \mathrm{E}-05$ & ----- & ----- & ----- & ----- & ----- & ----- \\
\hline & Cd & 000.00914 & $5.00 \mathrm{E}-04$ & $2.74 \mathrm{E}-06$ & $7.62 \mathrm{E}-06$ & $8.88 \mathrm{E}-06$ & $5.48 \mathrm{E}-03$ & $1.5 \mathrm{EE}-02$ & $1.78 \mathrm{E}-02$ \\
\hline & $\mathbf{P b}$ & ND & $4.00 \mathrm{E}-04$ & --- & ---- & ---- & --- & --- & --- \\
\hline & $\mathbf{U}$ & 001.95300 & $3.00 \mathrm{E}-03$ & $0.59 \mathrm{E}-03$ & $1.63 \mathrm{E}-03$ & $1.90 \mathrm{E}-03$ & $1.96 \mathrm{E}-01$ & $5.423 \mathrm{E}-01$ & $6.33 \mathrm{E}-01$ \\
\hline & Th & 000.08260 & $1.80 \mathrm{E}-03$ & $2.48 \mathrm{E}-05$ & $6.88 \mathrm{E}-05$ & $8.03 \mathrm{E}-05$ & $1.38 \mathrm{E}-02$ & $3.82 \mathrm{E}-02$ & $4.46 \mathrm{E}-02$ \\
\hline & As & 000.45800 & $1.10 \mathrm{E}-03$ & $1.37 \mathrm{E}-04$ & $3.82 \mathrm{E}-04$ & $4.45 \mathrm{E}-04$ & $0.14 \mathrm{E} 00$ & $0.38 \mathrm{E} 00$ & $0.41 \mathrm{E} 00$ \\
\hline \multirow{8}{*}{ 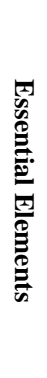 } & $\mathbf{K}$ & 113.31000 & $4.00 \mathrm{E}-02$ & $3.40 \mathrm{E}-02$ & $9.44 \mathrm{E}-02$ & $11.01 \mathrm{E}-02$ & $8.50 \mathrm{E}-01$ & 2.36E 00 & 2.75E 00 \\
\hline & Sn & 000.00360 & $8.60 \mathrm{E}-03$ & $1.08 \mathrm{E}-06$ & $3.00 \mathrm{E}-06$ & $3.50 \mathrm{E}-06$ & $1.26 \mathrm{E}-04$ & $3.49 \mathrm{E}-04$ & $4.07 \mathrm{E}-04$ \\
\hline & Ca & 518.02800 & $2.00 \mathrm{E}-02$ & $1.56 \mathrm{E}-01$ & $4.32 \mathrm{E}-01$ & $5.03 \mathrm{E}-01$ & $7.80 \mathrm{E} 00$ & 21.60Е00 & 25.15E 00 \\
\hline & $\mathbf{N i}$ & 000.08700 & $2.00 \mathrm{E}-02$ & $2.61 \mathrm{E}-05$ & $7.25 \mathrm{E}-05$ & $8.45 \mathrm{E}-05$ & $1.31 \mathrm{E}-03$ & $3.63 \mathrm{E}-03$ & $4.23 \mathrm{E}-03$ \\
\hline & $\mathrm{Cu}$ & ND & $4.00 \mathrm{E}-02$ & --- & --- & --- & --- & --- & --- \\
\hline & $\mathbf{F e}$ & 003.18700 & $7.00 \mathrm{E}-01$ & $0.96 \mathrm{E}-03$ & $2.66 \mathrm{E}-03$ & $3.10 \mathrm{E}-03$ & $1.37 \mathrm{E}-03$ & $3.80 \mathrm{E}-03$ & $4.43 \mathrm{E}-03$ \\
\hline & Co & 000.00360 & $3.00 \mathrm{E}-04$ & $1.08 \mathrm{E}-06$ & $3.00 \mathrm{E}-06$ & $3.50 \mathrm{E}-06$ & $3.60 \mathrm{E}-03$ & $1.00 \mathrm{E}-02$ & $1.17 \mathrm{E}-02$ \\
\hline & Mn & 000.30170 & $4.60 \mathrm{E}-02$ & $9.05 \mathrm{E}-05$ & $2.52 \mathrm{E}-04$ & $2.93 \mathrm{E}-04$ & $1.97 \mathrm{E}-03$ & $5.47 \mathrm{E}-03$ & $6.37 \mathrm{E}-03$ \\
\hline
\end{tabular}

Also the results showed that, the activity of the ratio ${ }^{238} \mathrm{U} /{ }^{226} \mathrm{Ra}$ ranged from 0.91 to 2.31 , The highest ${ }^{238} \mathrm{U} /{ }^{226} \mathrm{Ra}$ concentration $(2.31 \mathrm{~Bq} / \mathrm{Kg})$ was in the fish samples from frozen Herring (Philippines), and in samples (2, 3, and 9), this meant that there was excess in ${ }^{238} U$ due to the extraction of uranium from the water or from the accumulation of uranium on gill surfaces. ${ }^{226} \mathrm{Ra} /{ }^{232} \mathrm{Th}$ ratios indicate that in fish samples $(1,3,9,10){ }^{226} \mathrm{Ra}$ was in excess to ${ }^{232} \mathrm{Th}$, this is due to water interaction with samples. ${ }^{137} \mathrm{Cs}$ was detectable in the fish samples except in sample 1 (fresh Seagan), the highest value of ${ }^{137} \mathrm{Cs}$ content is in sample 5 (frozen herring) $1.44 \mathrm{~Bq} / \mathrm{kg}$ and the lowest value is $0.63 \mathrm{~Bq} / \mathrm{kg}$ in sample 7 (Shrimp). The allowed level of ${ }^{137} \mathrm{Cs}$ activity for foodstuffs is $1000 \mathrm{~Bq} / \mathrm{kg}$ [27].

So, there is no hazard to public health from the ${ }^{137} \mathrm{Cs}$ activity in fish samples in the present study.

\subsection{The Annual Effective Dose ( $\mu \mathrm{Sv} / \mathrm{y})$ Estimation for Different Age Group}

Table 6 represents the calculated age-dependent annual effective dose $(\mu \mathrm{Sv} / \mathrm{y})$ due to intake contaminated fish with radiation. The annual effective dose $(\mu \mathrm{Sv} / \mathrm{y})$ of ${ }^{238} \mathrm{U}$ for Infants $(\leq 5 \mathrm{y})$ ranged from 0.07 to 0.22 with an average 0.13 , for children ( $5-10 \mathrm{y}, 10-15 \mathrm{y}$ ) from 0.30 to 0.92 with average 0.55 , and from 0.58 to1.8 with an average 1.09 respectively, for adults $(\geq 17 \mathrm{y})$ from 1.74 to 5.38 with an average 3.25 . The annual effective dose $\left(\mu \mathrm{Sv} / \mathrm{y}\right.$ ) of ${ }^{226} \mathrm{Ra}$ for Infants ( $\leq 5 \mathrm{y}$ ) varied from 0.47 to 1.56 with an average 0.99 , for children (5- $10 \mathrm{y}, 10-15 \mathrm{y}$ ) from 3.00 to 10.80 with average 6.39 , and from 11.25 to 40.50 with an average 23.97 respectively, for adults ( $\geq 17 \mathrm{y}$ ) from 5.25 to 18.90 with an average 11.86 . The annual effective dose $(\mu \mathrm{Sv} / \mathrm{y})$ of ${ }^{232} \mathrm{Th}$ for Infants $(\leq 5 \mathrm{y})$ were from 0.29 to 0.39 with an average 0.58 , for children ( 5 - 10 y, $10-15$ y) from 1.22 to 3.87 with average 2.41, and from 2.10 to 6.68 with an average 4.16 respectively, for adults ( $\geq 17$ y) from 4.83 to 15.35 with an average 9.56. The annual effective dose $(\mu \mathrm{Sv} / \mathrm{y})$ of ${ }^{40} \mathrm{~K}$ for Infants ( $\left.\leq 5 \mathrm{y}\right)$ were from 0.29 to 7.40 with an average 4.37, for children ( $5-10 \mathrm{y}, 10-15 \mathrm{y}$ ) from 0.91 to 22.90 with average 13.53 , and from 1.07 to 26.78 with an average 15.82 respectively, for adults ( $\geq 17 \mathrm{y})$ from 2.17 to 54.61 with an average $32.26(\mu \mathrm{Sv} / \mathrm{y})$. The total average annual effective dose $(\mu \mathrm{Sv} / \mathrm{y})$ for all groups were $6.07,22.88,45.03$, and 56.26 respectively. The results of the present work show that the lowest total average annual effective dose $(\mu \mathrm{Sv} / \mathrm{y})$ value due to the radiation in fish was for infants, while the largest was for adults. This is due to the amount of fish consumed by each group.

Table 7 shows the comparison of the Average concentration $\mathrm{Bq} / \mathrm{Kg}$ and the total average annual effective dose $(\mu \mathrm{Sv} / \mathrm{y})$ values of this study and the values of similar studies. The highest concentration values for natural 


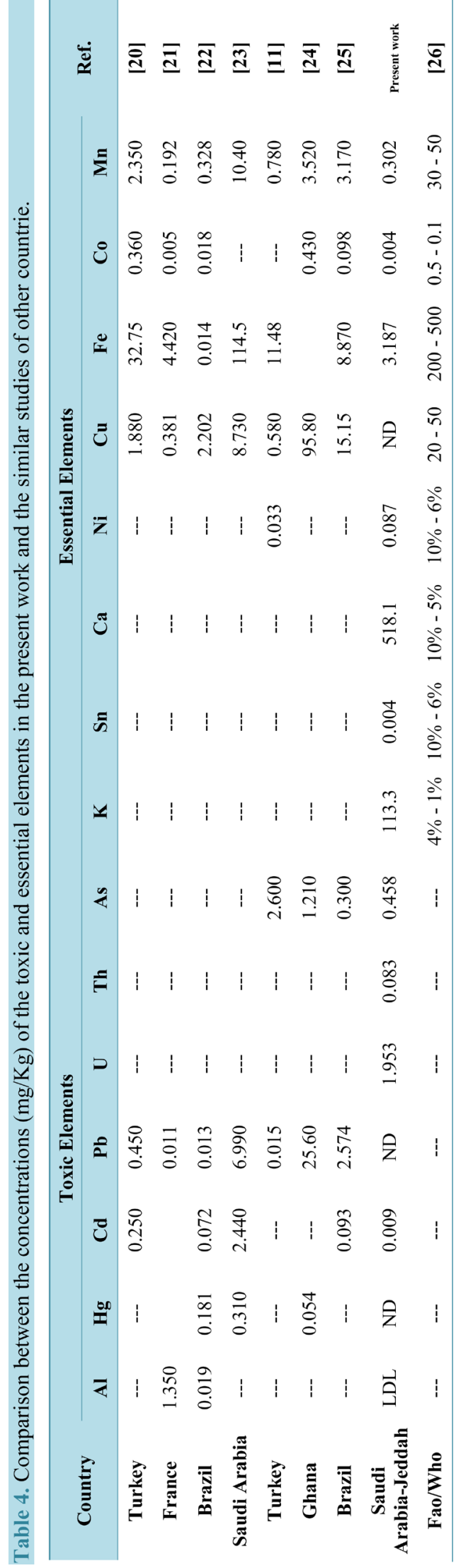


Table 5. The specific radioactive concentrations in $\mathrm{Bq} / \mathrm{kg}$ dry weight for fish samples.

\begin{tabular}{cccccccc}
\hline \multirow{2}{*}{ Sa. no. } & \multicolumn{3}{c}{ Radioactivity Concentrations (Bq/kg) of Radionuclides in Fish } & \multicolumn{3}{c}{ Ratio of } \\
\cline { 2 - 8 } & ${ }^{238} \mathbf{U}$ & ${ }^{226} \mathbf{R a}$ & ${ }^{232} \mathbf{T h}$ & ${ }^{40} \mathbf{K}$ & ${ }^{137} \mathbf{C s}$ & ${ }^{238} \mathbf{U} /{ }^{226} \mathbf{R a}$ & ${ }^{226} \mathbf{R a}{ }^{232} \mathbf{T h}$ \\
\hline S1 & $1.44 \pm 0.01$ & $1.58 \pm 0.02$ & $2.26 \pm 0.02$ & $287.03 \pm 0.01$ & $L^{*}$ & 0.91 & 0.70 \\
S2 & $2.60 \pm 0.02$ & $2.51 \pm 0.01$ & $1.99 \pm 0.02$ & $238.05 \pm 0.01$ & $0.78 \pm 0.01$ & 1.04 & 1.26 \\
S3 & $2.48 \pm 0.01$ & $2.10 \pm 0.02$ & $2.67 \pm 0.02$ & $202.27 \pm 0.01$ & $0.80 \pm 0.01$ & 1.18 & 0.79 \\
S4 & $2.69 \pm 0.01$ & $2.70 \pm 0.02$ & $2.33 \pm 0.03$ & $352.32 \pm 0.02$ & $0.93 \pm 0.01$ & 1.00 & 1.16 \\
S5 & $2.38 \pm 0.02$ & $1.03 \pm 0.02$ & $0.84 \pm 0.02$ & $292.14 \pm 0.03$ & $1.44 \pm 0.01$ & 2.31 & 1.23 \\
S6 & $1.59 \pm 0.02$ & $1.57 \pm 0.02$ & $0.93 \pm 0.03$ & $171.03 \pm 0.03$ & $1.13 \pm 0.02$ & 1.01 & 1.69 \\
S7 & $0.92 \pm 0.02$ & $0.93 \pm 0.02$ & $1.00 \pm 0.03$ & $37.60 \pm 0.03$ & $0.63 \pm 0.01$ & 0.99 & 0.93 \\
S8 & $1.28 \pm 0.01$ & $1.38 \pm 0.02$ & $1.24 \pm 0.01$ & $287.89 \pm 0.02$ & $1.07 \pm 0.02$ & 0.93 & 1.11 \\
S9 & $0.87 \pm 0.01$ & $0.75 \pm 0.01$ & $1.71 \pm 0.01$ & $198.96 \pm 0.01$ & $1.05 \pm 0.01$ & 1.16 & 0.44 \\
S10 & LDL & $1.43 \pm 0.01$ & $1.66 \pm 0.02$ & $14.02 \pm 0.01$ & $0.82 \pm 0.01$ &.-- & 0.86 \\
Average & 1.63 & 1.60 & 1.66 & 208.13 & 0.96 & & \\
\hline
\end{tabular}

Table 6. Annual effective dose $(\mu \mathrm{Sv} / \mathrm{y})$ due to the intake of natural radionuclides of ${ }^{238} \mathrm{U},{ }^{226} \mathrm{Ra},{ }^{232} \mathrm{Th}$ and ${ }^{40} \mathrm{~K}$ from the fish products.

\begin{tabular}{|c|c|c|c|c|c|}
\hline & & \multicolumn{4}{|c|}{ Effective dose $(\mu \mathrm{Sv} / \mathrm{y})$} \\
\hline \multicolumn{2}{|c|}{ Radionuclide } & \multirow{2}{*}{$\begin{array}{c}\text { Infants } \\
\leq 5 \mathrm{y}\end{array}$} & \multicolumn{2}{|c|}{ Children } & \multirow{2}{*}{$\begin{array}{l}\text { Adults } \\
\geq 17 \mathrm{y}\end{array}$} \\
\hline & & & $5-10 y$ & $10-15 y$ & \\
\hline \multirow{3}{*}{${ }^{238} \mathbf{U}$} & Minimum & 0.07 & 0.30 & 0.58 & 1.74 \\
\hline & Maximum & 0.22 & 0.92 & 1.8 & 5.38 \\
\hline & Average & 0.13 & 0.55 & 1.09 & 3.25 \\
\hline \multirow{3}{*}{${ }^{226} \mathbf{R a}$} & Minimum & 0.47 & 3.0 & 11.25 & 5.25 \\
\hline & Maximum & 1.56 & 10.8 & 40.5 & 18.90 \\
\hline & Average & 0.99 & 6.39 & 23.97 & 11.86 \\
\hline \multirow{3}{*}{${ }^{232} \mathrm{Th}$} & Minimum & 0.29 & 1.22 & 2.1 & 4.83 \\
\hline & Maximum & 0.39 & 3.87 & 6.68 & 15.35 \\
\hline & Average & 0.58 & 2.41 & 4.16 & 9.56 \\
\hline \multirow{3}{*}{${ }^{40} K^{22}$} & Minimum & 0.29 & 0.91 & 1.07 & 2.17 \\
\hline & Maximum & 7.40 & 22.90 & 26.78 & 54.61 \\
\hline & Average & 4.37 & 13.53 & 15.82 & 32.26 \\
\hline \multicolumn{2}{|c|}{ Total Average } & 6.07 & 22.88 & 45.03 & 56.26 \\
\hline \multicolumn{2}{|c|}{ *UNSCEAR 2013} & 14.9 & 25.3 & 37.1 & 37.1 \\
\hline
\end{tabular}

${ }^{*}[28]$.

Table 7. Describe the Average concentration $\mathrm{Bq} / \mathrm{Kg}$, the total average annual effective dose ( $\mu \mathrm{Sv} / \mathrm{y})$ values of this study and the values of similar studies.

\begin{tabular}{|c|c|c|c|c|c|c|c|c|c|c|}
\hline \multirow{2}{*}{ Location } & \multicolumn{5}{|c|}{ average concentration $\mathbf{B q} / \mathbf{K g}$} & \multicolumn{4}{|c|}{ Total average annual effective dose $(\mu \mathrm{Sv} / \mathrm{y})$} & \multirow{2}{*}{ Reference } \\
\hline & ${ }^{238} \mathbf{U}$ & ${ }^{226} \mathbf{R a}$ & ${ }^{232} \mathrm{Th}$ & ${ }^{40} \mathbf{K}$ & ${ }^{137} \mathrm{Cs}$ & ${ }^{238} \mathbf{U}$ & ${ }^{226} \mathrm{Ra}$ & ${ }^{232} \mathrm{Th}$ & ${ }^{40} \mathrm{~K}$ & \\
\hline Hong Kong & 0.018 & 0.005 & 0.47 & 86.65 & 0.11 & 0.018 & 0.083 & 2.585 & -- & [29] \\
\hline Oman & 0.49 & -- & 0.40 & 134.0 & 0.33 & -- & -- & -- & -- & {$[30]$} \\
\hline Nigeria & -- & 1.860 & 1.65 & 58.00 & -- & -- & -- & -- & -- & [31] \\
\hline Kainji lake & -- & 37.22 & 94.82 & 384.98 & -- & -- & 29.802 & 28.77 & 9.73 & [32] \\
\hline Brazil & 0.05 & 0.19 & 0.06 & -- & -- & -- & -- & -- & -- & [33] \\
\hline Saudi Arabia Jeddah & 1.63 & 1.60 & 1.66 & 208.13 & 0.96 & & & & & Present Work \\
\hline
\end{tabular}


radionuclides ${ }^{238} \mathrm{U},{ }^{226} \mathrm{Ra},{ }^{232} \mathrm{Th},{ }^{40} \mathrm{~K}$, and ${ }^{137} \mathrm{Cs}$ were in Kainji lake Nigeria, while the lowest values were inHong Kong. The total average annual effective dose values were not found in the most of the studies.

\section{Conclusion}

This study has been carried out to analyze the concentrations $\mathrm{mg} / \mathrm{Kg}$, The daily intakes (EDI) $\mathrm{mg} / \mathrm{kg}$ body weight/day, and hazarded indices (HIs) of some toxic and essential metals in ten fish samples. The concentrations of the elements $(\mathrm{Al}, \mathrm{Hg}, \mathrm{Pb}$ and $\mathrm{Cu}$ ) in all fish samples were not detected or below the detection limit. The concentrations of metals (Cd, U, Th, As, K, Sn, Ca, Ni, Fe, Co, and Mn) were below the recommended limit by the international organizations. The estimated metal dose (EDI) values for daily average consumption were lower than the recommended values of FAO/WHO (2004), and hazard indices (HI) in fish samples were below safety levels for human consumption $(\mathrm{HI}<1)$ except $(\mathrm{HI})$ for Ca element with values were greater than one $(>1)$, this increase in Ca element is to be of concern for fish consumer. Also, the natural radioactivity and fallout ${ }^{137} \mathrm{Cs}$ levels $(\mathrm{Bq} / \mathrm{Kg})$ dry weight of gamma-emitters in ten fish samples were determined. The results show that the activity concentrations and the total average annual doses $\mu \mathrm{Sv} / \mathrm{y}$ (calculated for infants, children and for adults) received from the intake of ${ }^{226} \mathrm{Ra}{ }^{232} \mathrm{Th}$ and ${ }^{40} \mathrm{~K}$ due to the ingestion of the fish were of no risk to public health. All these average doses are less than the annual dose limit of $1 \mathrm{mSv} / \mathrm{y}$ and the contribution of ${ }^{137} \mathrm{Cs}$ is nearly negligible. In both techniques, the results were compared with the study results in other countries. The values were varied from one country to another due to the different types of fish, food habit, and the environment in which these fish were lived. On the basis of the results of this study, it appears that more specifications are needed for imported types of fish and the sources and the environment in which the fish were lived is to be of concern for researchers.

\section{References}

[1] Esra, A., Ahmet, O.S. and Karadede, A.H. (2009) Heavy Metal Concentrations in Two Barb, Barbusxanthopterus and Barbusrajanorummystaceus from Atatürk Dam Lake, Turkey. Environmental Monitoring and Assessment, $148,11$.

[2] Küpeli, T., Altundağ, H. and İmamoğlu, M. (2014) Assessment of Trace Element Levels in Muscle Tissues of Fish Species Collected from a River, Stream, Lake, and Sea in Sakarya, Turkey. The Scientific World Journal, 2014, Article ID: 496107.

[3] Uysal, K. (2011) Heavy Metal in Edible Portion (Muscle and Skin) and Other Organs (Gill Liver and Intestine) of Selected Freshwater Fish Species. International Journal of Food Properties, 14, 280-286.

[4] Ashraf, M.A., Maah, M.J. and Yusoff, I. (2012) Bioaccumulation of Heavy Metals in Fish Species Collected from Former Tin Mining Catchment. International Journal of Environmental Research, 6, 209-218.

[5] Carvalho Fernando, P. and Oliveira Joao, M. (2008) Radioactivity in Marine Organisms from Northeast Atlantic Ocean. The Natural Radiation Environment-8th International Symposium.

[6] Hassona Rifaat, K., Sam, A.K., Osman, O.I., Sirelkhatim, D.A. and La, R.J. (2008) Assessment of Committed Effective Dose Due to Consumption of Red Sea Coral Reef Fishes Collected from the Local Market (Sudan). Science of the Total Environment, 393, 214-218 http://web.ornl.gov/sci/env_rpt/aser97/aser.htm

[7] ICRP (1996) Conversion Coefficients for Use in Radiological Protection against External Radiation. ICRP Publication 74. Ann. http://www.icrp.org/publication.asp?id=ICRP\%20Publication\%2074

[8] Wang, X., Sato, T., Xing, B. and Tao, S. (2005) Health Risk of Heavy Metals to the General Public in Tianjin, China via Consumption of Vegetables and Fish. Science of the Total Environment, 350, 28-37.

[9] Akoto, O., Bismark Eshun, F., Darko, G. and Adei, E. (2014) Concentrations and Health Risk Assessments of Heavy Metals in Fish from the Fosu Lagoon. International Journal of Environmental Research, 8, 403-410.

[10] Zhuang, P.B., McBride, M., Xia, H., Li, N. and Li, Z. (2009) Health Risk from Heavy Metals via Dabaoshan Mine, South China. Science of the Total Environment, 407, 1551-1561. http://dx.doi.org/10.1016/j.scitotenv.2008.10.061

[11] Korkmaz Görür, F., Keser, R., Akçay, N. and Dizman, S. (2012) Radioactivity and Heavy Metal Concentrations of Some Commercial Fish Species Consumed in the Black Sea Region of Turkey. Chemosphere, 87, 356-361. http://dx.doi.org/10.1016/j.chemosphere.2011.12.022

[12] UNSCEEAR (2008) Sources of Ionizing Radiation, Report Vol. 1 US-EPA. United States Environmental Protection Agency.

[13] Amrani, D. and Tahtat, M. (2001) Natural Radioactivity in Algerian Building Materials. Applied Radiation and Isotopes, 54, 687-689. http://dx.doi.org/10.1016/S0969-8043(00)00304-3 
[14] UNSCEAR (2000) United Nations Scientific Committee on the Effects of Atomic Radiation. Sources and Effects of Ionizing Radiation, Vol. 1, United Nations Publication, New York.

[15] EC (2005) European Community. Commission Regulation No 78/2005. Official Journal of the European Union (20.1.2005), L16/43-L16/45.

[16] IAEA (2005) International Atomic Energy Agency, Annual Report. https://www.iaea.org/publications/reports/annual-report-2005

[17] USFDA (1993) United States Food and Drug Administration, Guidance Document for Chromium in Shell Fish. DHHS/PHS/FDA/CFSAN/Office of Seafood, Washington DC.

[18] FAO/WHO Expert Committee on Food Additives (JECFA 1956-2003), (First Through Sixty First Meetings). ILSI Press International Life Sciences Institute.

[19] EPA (2015) Risk-Based Screening Table—Generic Tables, RfD mg/kg Body Weight/Day for Elements. www.epa.gov/risk/risk-based-screening-table-generic-tables

[20] Mendil, D., Demirci, Z., Tuzen, M. and Soylak, M. (2010) Seasonal Investigation of Trace Element Contents in Commercially Valuable Fish Species from the Black Sea, Turkey. Food and Chemical Toxicology, 48, 865-870.

[21] Guérin, T., Chekri, R., Vastel, C., Sirot, V., Volatier, J.-L., Leblanc, J.-C. and Noël, L. (2011) Determination of 20 Trace Elements in Fish and Other Seafood from the French Market. Food Chemistry, 127, 934-942. http://dx.doi.org/10.1016/j.foodchem.2011.01.061

[22] Grotto, D., Batista, B.L., HornosCarneiro, M.F. and Barbosa Jr., F. (2012) Evaluation by ICP-MS of Essential, Nonessential and Toxic Elements in Brazilian Fish and Seafood Samples. Food and Nutrition Sciences, 3, 1252-1260

[23] Alturiqi, A.S. and Albedair, L.A. (2012) Evaluation of Some Heavy Metals in Certain Fish, Meat and Meat Products in Saudi Arabian Markets. Egyptian Journal of Aquatic Research, 38, 45-49.

[24] Kwaansa-Ansah, E.E, Akoto, J., Adimado, A.A. and Nam, D. (2012) Determination of Toxic and Essential Elements in Tilapia Species from the Volta Lake with Inductively Coupled Plasma-Mass Spectrometry. International Journal of Environmental Protection (IJEP), 2, 30-34.

[25] Jurema, M.R., dos Santosa, L.M.G., Goncalvesa, J.M., Bragab, A.M.C.B., Kraussb, T.M. and do Couto Jacob, S. (2014) Comparison of the Nutritional and Toxicological Reference Values of Trace Elements in Edible Marine Fish Species Consumed by the Population in Rio De Janeiro State, Brazil. Toxicology Reports, 1, 353-359. http://dx.doi.org/10.1016/j.toxrep.2014.06.005

[26] FAO/WHO (2004) Evaluation Certain Food Additives and Ingredients by the Joint FAO/WHO Expert Committee on Food Additives (JECFA).

[27] ICRP (2004) 26 (3-4). ICRP. Release of Patients after Therapy with Unsealed Radionuclides. ICRP Publication 94. Ann. ICRP 34 (2).

[28] UNSCEAR (1993) Sources and Effects of Ionizing Radiation, Report to the General Assembly, with Scientific Annexes. New York.

[29] Yu, K.N., Mao, S.Y., Young, E.C.M. and Stokes, M.J. (1997) A Study of Radioactivities in Six Types of Fish Consumed in Hong Kong. Applied Radiation and Isotopes, 48, 515-519. http://dx.doi.org/10.1016/S0969-8043(96)00283-7

[30] Goddard, C.C., Mathews, C.P. and Al Mamry, J. (2003) Baseline Radionuclide Concentrations in Omani Fish. Marine Pollution Bulletin, 46, 903-917. http://dx.doi.org/10.1016/S0025-326X(03)00105-X

[31] Sowole, O. (2011) Dose Rates of Natural Radioactivities in Fishes from Rivers in Sagamu Ogun State Nigeria. Canadian Journal of Pure Applied Science, 5, 1729-1732.

[32] Adamu, R., Zakari, Y.I., Ahmed, A.Y., Abubakar, S. and Vatsa, A.M. (2013) Analysis of Activity Concentrations Due to Natural Radionuclides in the Fish of Kainji Lake. Advances in Applied Science Research, 4, 283-287.

[33] Pereira Wagner de S., PyJúnior, D. de A. and Kelecom, A. (2009) Concentration Activities of Natural Radionuclides in Three Fish Species in Brazilian Coast and Their Contributions to the Absorbed Doses. International Nuclear Atlantic Conference, Rio de Janeiro, 27 September-2 October 2009. 